\title{
Article
}

\section{Word of Mouth, Digital Media, and Open Innovation at the Agricultural SMEs}

\author{
Tutur Wicaksono ${ }^{1}\left(\mathbb{D}\right.$, Agus Dwi Nugroho ${ }^{1,2, *}$, Zoltán Lakner ${ }^{3}$, Anna Dunay ${ }^{3}$ and Csaba Bálint Illés ${ }^{3}$ \\ 1 Doctoral School of Economic and Regional Sciences, Hungarian University of Agriculture and Life Sciences, \\ 2100 Godollo, Hungary; tuturwicaksono18@gmail.com or Wicaksono.Tutur@hallgato.uni-szie.hu (T.W.) \\ 2 Department of Agricultural Socio Economics, Faculty of Agriculture, Universitas Gadjah Mada, \\ Yogyakarta 55281, Indonesia \\ 3 Institute of Economic Sciences, Hungarian University of Agriculture and Life Sciences, 2100 Godollo, \\ Hungary; Lakner.Zoltan.Karoly@uni-mate.hu (Z.L.); Dunay.Anna@uni-mate.hu (A.D.); \\ Illes.Balint.Csaba@uni-mate.hu (C.B.I.) \\ * Correspondence: agus.dwi.n@mail.ugm.ac.id
}

check for

updates

Citation: Wicaksono, T.; Nugroho, A.D.; Lakner, Z.; Dunay, A.; Illes, C.B. Word of Mouth, Digital Media, and Open Innovation at the Agricultural SMEs. J. Open Innov. Technol. Mark. Complex. 2021, 7, 91. https:// doi.org/10.3390/joitmc7010091

Received: 8 February 2021

Accepted: 3 March 2021

Published: 9 March 2021

Publisher's Note: MDPI stays neutral with regard to jurisdictional claims in published maps and institutional affiliations.

Copyright: (c) 2021 by the authors. Licensee MDPI, Basel, Switzerland. This article is an open access article distributed under the terms and conditions of the Creative Commons Attribution (CC BY) license (https:// creativecommons.org/licenses/by/ $4.0 /)$.

\begin{abstract}
Small and medium enterprises (SMEs) must continue to combine technology and market adaptation or open innovation to sustain their business. One of these ways is to promote their products and services extensively. This study investigated the best media to promote SMEs in the local agricultural markets of Hungary. This study uses an approach of asking consumers where they receive information about SMEs and their determinants. Research questionnaires were distributed to 156 consumers who purchased agricultural products on the Budapest Central Market Hall. The data were analyzed using a binary logistic model. The studies showed that consumers obtain market information through word-of-mouth and digital media. Older consumers tend to receive information through word-of-mouth, while consumers who rarely interact with others or who are educated or foreign choose digital media. Therefore, SMEs in Hungary's local agricultural markets have yet to focus on developing promotional activities through these two media. For the future, recommendations are given to SMEs in Hungary to maintain the quality of products and services and to develop two-way communication in digital media (e-WOM).
\end{abstract}

Keywords: markets; information; age; social interaction; education; nationality

\section{Introduction}

The Covid-19 pandemic has proven to have a destructive impact on small and medium enterprises (SMEs) in Europe. The operations and profits of SMEs will plunge significantly relative to the previous year. Up to now, numerous government policies have not been able to neutralize the effect of the Covid-19 on SMEs [1]. This led to the idea for SMEs to continually innovate to survive during this pandemic.

Prasanna et al. [2] concluded that SMEs need to innovate and respond to new technology in order to face global competition. Yun and Zhao [3] stated that open innovation, focused on a new combination between technology and adaptation to the market, is the engine to make a sustainable business. The Covid-19 pandemic has encouraged consumers to use online communication technology to minimize direct interaction with many peoples. This means SMEs need to adapt their marketing situation during the Covid-19 pandemic, to either use conventional methods, word-of-mouth (WoM), or follow current trends with digital media.

Consumers receive market information from a variety of sources, including digital media and WoM. Promotion through digital media is a marketing trend and can be achieved through the internet, social media, e-advertising, and others. This media is capable of efficiently distributing product or service information and growing brand recognition and sales [4]. Digital media is able to reach consumers broadly and quickly [5]. However, there 
is another media, WoM, which is described as one-to-one and face-to-face for product or service information exchanges [6]. It is based on the consumer experience after consuming a product or using a service [7]. WoM is proven to have a very powerful impact on a consumer's decision to purchase or not to purchase [8]. However, King et al. [9] stated that WoM could become less effective if people did not understand the message.

Central Europe is one region where SMEs need to care about relevant promotional media because of its large market reach. The marketing area of SMEs in Central Europe is not only in urban areas but is also able to reach rural areas. They are growing dynamically to replace state-owned and cooperative stores $[10,11]$. SMEs in Central Europe also have an important role to play in sustainable economic growth, post-transformation processes, and the integration of formal and informal organizations [12,13]. Even with their various innovations, SMEs in Central Europe have been able to export products after the deep economic recession in 2007 [14]. The European Union (EU) also offers large funds to help them continue to innovate [15].

Hungary is one of the few countries in Central Europe that can make good use of these EU funds (both grants and financial instruments) for micro-business growth [16]. Moreover, SMEs in Hungary have proven capable of overcoming financial difficulties, as shown by their response to the 2008 recession, even as the Hungarian Government was facing a serious financial crisis at the time [17]. This is still supported by the fact that SME innovation in Hungary continues to grow. However, this innovation was not related to marketing. The marketing innovation of SMEs in Hungary was in the bottom five ranks relative to other EU countries. This is getting worse because Hungary is one of the countries in the EU where SMEs face the most barriers [18]. Another surprising fact is that Hungary is the most-developed country with the highest downgrade ranking of digital future-readiness in the world, from 45 in 2016 to 60 in 2020 [19].

According to Worldometers statistics, the average age of the Hungarian population is 43.3 years. At this age, people should be interested in using digital media [20]. This situation is confusing for SMEs in Hungary since their target market uses more digital media, but Hungary's digital readiness is actually getting lower. These various conditions influenced us to focus this study more on Hungary than other areas.

We chose agriculture and food SMEs as the focus of this study because they face the most barriers compared to other SMEs. They must compete with each other, face the risk of perishable products, can succumb to price volatility, meet high safety standards, as well as raise consumer sensitivity to social, environmental, and ethical concerns $[11,21,22]$. Regulations and the role of government in supporting agricultural economic growth are still not adequate and cause SMEs to be disappointed [23]. Moreover, the quality of human capital and digital literacy for managers of agriculture and food SMEs in Central Europe, including Hungary, is poorer than in other EU countries [24]. This results in agriculture and food SMEs being the most insecure businesses relative to other SMEs.

Today, agriculture and food SMEs must continue to carry out promotions to increase sales growth and finally create higher profit for SMEs $[25,26]$. However, it is not easy for SMEs to carry out many promotions due to cost constraints and the diversity of target markets. SMEs must be observant for determining promotional media that are effective in targeting consumers and in their budgets [27].

We also consider that our results can be generalized as a good lesson for many agriculture and food SMEs in other regions. First, there are many economic and cultural similarities between Hungary and other Central-European countries, where there has been a "belated and back warded" socio-economic development as a consequence of a specific historical development path. The main specific features of these countries relevant for our analysis are the following: (a) after the dissolution of state-farms and cooperatives, there has been a rapid increase in the number of SMEs in the agricultural sector; (b) food industry privatization has been mainly accomplished by foreign direct investment, and this is why there is a lack of knowledge on the implementation of various modern communication methods; (c) as a consequence of economic transformation and privatization, a bipolar 
agricultural and food trade sector has been formed including, on the one hand, large concentrated economic entities and, on the other hand, a large number of SMEs often with backward processing capacities; (d) considerable income differences among the population; and (e) rapidly changing consumer habits, e.g., increasing importance of eating away from home and rapid proliferation of snack bars. Second, Hungary as a "test-tube" can be considered as a "model" from the point of view of forecasting the expected processes in other, relatively lesser developed states, e.g., the West-Balkan and areas in Ukraine, Belarus, Russia, and regions dominated by post-soviet culture, e.g., Kazakhstan. As a summary, we consider our article as a preliminary attempt to understand an important problem that can be well generalized in an economic region with 60-80 million consumers.

Next, we need to identify a place of gathering for agriculture and food SMEs to facilitate data collection during the Covid-19 pandemic. In our view, the agricultural market is the most representative location for this study. We will explain this in more detail in Section 3.1. However, based on the various conditions that we have previously disclosed, our study question is as follows:

What is the best media to promote SMEs in the agricultural local markets of Hungary?

To answer this question, we try to find out from where consumers receive information about agriculture and food SMEs in Hungary and their determinant factors. This approach is based on research by Reidolf [28], which claimed that SME innovation requires feedback from consumers. This is aligned with Yun and Zhao [3] who unveiled the Model Building of Cultivating Forward Neighborhood Rectangular Concept. The third point of this concept, the technological system, is relevant to this study. SMEs need to have strong ties with consumers in order to develop business models of evolution during and after the Covid-19 pandemic. In addition, this research is also relevant with the fifth point of this concept: connection with customer. The main aims of this study and philosophy are to make it easy for SMEs to maintain strong customer relations and to find new consumers.

After the Introduction, this article presents a literature review of factors that influence a person to obtain or choose market information (Section 2.1). The reader can find the theoretical framework of this study in Section 2.2. Next, Section 3 describes the location, data collection procedure, and the methodological framework in order to analyze the best media to promote SMEs in the agricultural local markets of Hungary. Results and Discussion are presented in Sections 4 and 5. Conclusions, Implications, Limitations, and Future Research are presented in Section 6.

\section{Literature Review and Theoretical Framework}

\subsection{Literature Review}

In order to survive fierce competition, an effective marketing strategy is required. This is implemented to reach large potential consumers easily and cost effectively [29]. Currently, effective marketing strategies are the main focus of SMEs to survive. Moreover, the current market trends are changing very fast along with the technological improvements that make it easier for consumers to access various market information. This can be the main reason why SMEs need up-to-date skills to use information and communication technologies (ICTs) [30].

Digital media is one of the ways to disseminate market information. Many SMEs choose this medium because it is easy to use, has little cost, provides information effectively, and offers features for customer feedback [31]. In addition to digital media, there is also information delivery through WoM. This is typically used by people who have a social proximity to express their satisfaction after consuming products or services [32].

Eisingerich et al. [33] claim that providing market information via WoM is slower and more expensive than via digital media. Meanwhile, not everyone is interested in participating in the WoM process [32]. However, it turns out that a lot of people prefer to use WoM. In fact, this also happens to consumers in developed countries where much of the population uses advanced ICTs. However, it turns out that there are also people in developed countries who still believe more in WoM [5]. This is what SMEs should 
understand: there are other factors that can also influence consumers in their choice of marketing information [30].

There are several factors that influence a person in obtaining or selecting information, both internal and external. First, age and gender are indicators of both physical and mental states. Differences in age and gender trigger differences in how consumers think, feel, see, want, and act [34]. It affects the transmission of market information as consumers choose sources of information that they can trust and may give different opinions. Some researchers have found evidence that increasing age and changing social values contribute to shifts in how consumers think and act [35-40].

Next, educational level influences consumer preferences in selecting and evaluating marketing information sources and in making decisions. This also results in a difference in consumers' cognitive ability to verify information such as products and services from friends, loved ones, and other consumers. Different abilities and levels of education will yield different results [37,41,42].

External factors also influence the source of consumer information. For example, mobile phones help to disseminate information [43-45]. Consumers prefer to browse for all information on their mobile phones rather than have to find information in conventional ways $[46,47]$. Consumers can search for information from their mobile phones through social media. This media started as a platform or medium where users would communicate with their peers. Users can create, provide, and share different types of information through social media $[48,49]$.

However, social media cannot make all consumers trust all information. They need strong social ties, such as family or close friends, before they can trust information [50]. SMEs need to understand that kinship relationships, such as with family and friends, are powerful intrapersonal networks to provide emotional and content control in the delivery of marketing information [51]. Moreover, the hoax phenomenon has become increasingly widespread, undermining consumer trust in market information [52-56]. This disruption allows consumers to have more trust in information from direct social interactions. This can be a medium for consumers to verify marketing information through a variety of supporting factors, such as who the person conveying the information is, how close the consumer's relationship is with the information conveyer, and how persuasive the information is. Not all of this can be retrieved from digital media [50,57].

All of this does not diminish the intensity with which consumers seek information through digital media. These media can overcome the barrier of physical distance between sources and recipients of information [58]. Consumers traveling from great distances or even from different countries do not have to waste time visiting an information source or searching for information [59]. Moreover, countries with a high intensity of digital technology would allow their citizens to use digital media [60]. Regular usage patterns, convenience, and quick access to information are other reasons why they prefer this medium. They already know how to verify the information from different sources to avoid false information from digital media [61]. They may also use digital media to find information while traveling to other regions.

\subsection{Theoretical Framework}

This study combines Consumer Behavior Theory with Model Building of Cultivating Forward Rectangular Neighborhoods Concept. Kotler et al. [62] stated that many factors influence the consumer's decision-making process. These factors come from both internal and external consumers. In this case, consumers receive market information from WoM or digital media (see Section 2.1). Then, consumers would integrate and evaluate these factors with current information sources for decision making. The result is that consumers make decisions on which information source and type to use and which products to buy or not to buy. This process would be a consideration for SMEs to develop innovative marketing strategies, especially promotions. Then, SMEs will innovative to communicate different information through existing media [3]. This process continues as consumers re-obtain and 
analyze this information to make a decision. This is the theoretical framework in this study, as shown in Figure 1.

In Sections 1 and 2.1 we introduce two advertising media, including WoM and digital media. However, there is no guarantee that either media will be successful in promoting products or services. This is also true for consumers in developed countries where a large proportion of the population uses sophisticated ICTs. However, it turns out that even in developed countries there are people who still believe more in WoM [5]. There is a gap here as to which media, with their many characteristics, are successful for disseminating information, especially for promoting SME products and services to consumers.

The novelty of this study is the addition of the nationality variable to the research model. Previous research (see Section 2.1) has shown that several factors influence consumers' sources of information before making a decision, but none of them has included the nationality variable. Nationality may indeed be a variable that determines an individual's decision-making process [63].

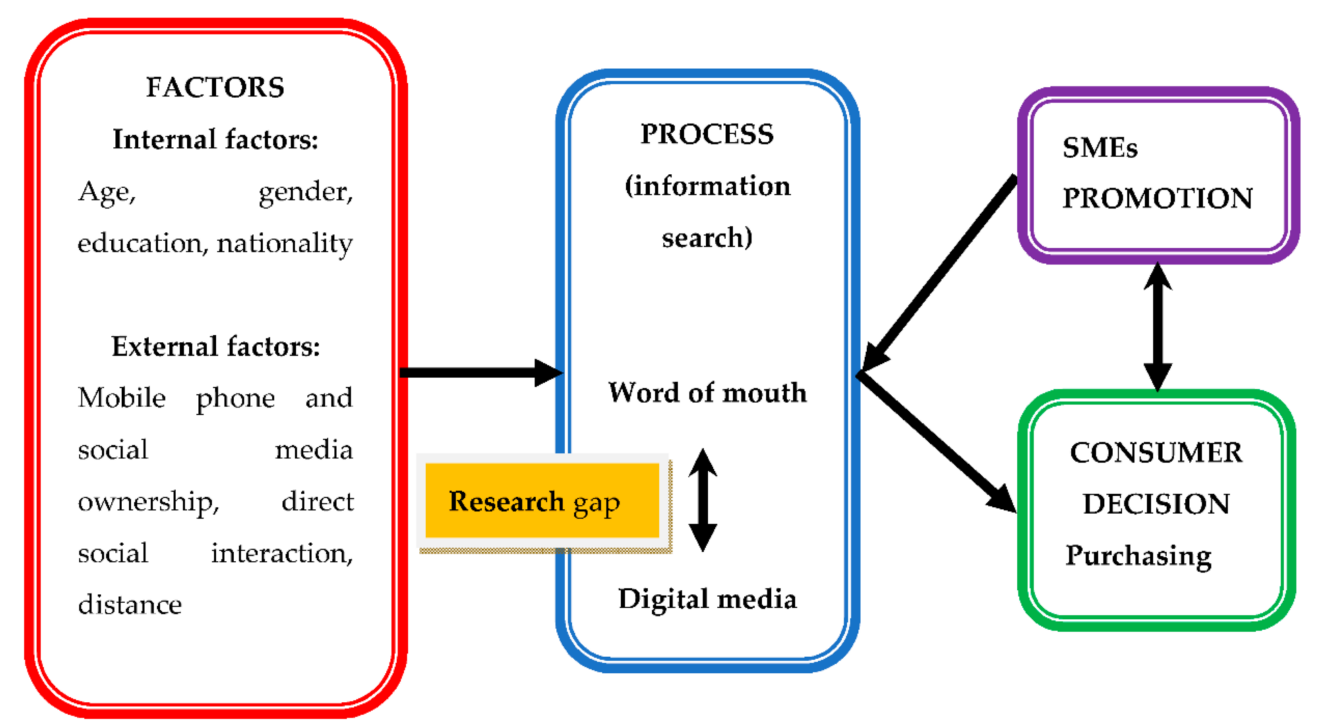

Figure 1. Theoretical framework of this study. SMEs, small and medium enterprises.

In this study we used nationality to distinguish between Hungarian citizens and migrants visiting Hungary (foreigners). This is to show whether the different status of locals and foreigners leads to differences in consumer behavior and considerations when exploring market information sources.

As we presented in Section 2.1, demographic, social, and technological factors influence consumers' use of information sources. According to Kotler et al. [62], the demographic factor consists of the variables of population size and density, location or distance, age, gender, education, occupation, nationality, and other statistics. The social factor consists of the social interaction and responsible behavior variables. The technological factor consists of the new technology and new product variables. However, only some of these variables are used in this study. Thus, the hypotheses in this study are as follows:

Hypothesis 1. Age has a significant impact on consumers' use of an information source.

Hypothesis 2. Gender has a significant impact on consumers' use of an information source.

Hypothesis 3. Education has a significant impact on consumers' use of an information source.

Hypothesis 4. Mobile phone ownership has a significant impact on consumers' use of an information source. 
Hypothesis 5. Direct social interaction has a significant impact on consumers' use of an information source.

Hypothesis 6. Social media ownership has a significant impact on consumers' use of an information source.

Hypothesis 7. Distance has a significant impact on consumers' use of an information source

Hypothesis 8. Nationality has a significant impact on consumers' use of an information source.

\section{Materials and Methods}

\subsection{Location}

The research was conducted in the Budapest Central Market Hall (the BCMH) because this place is the most visited agricultural local market in Hungary. Under regular conditions, the total number of visitors to this market is about 50,000 per day, which is higher than other agricultural local markets that have only 1000 to 15,000 visitors per day [64]. They buy agricultural products as a tourist would. The consumers in this market are not only Hungarian residents, but also foreigners (non-Hungarians). However, due to the Covid-19 pandemic, the number of visitors has drastically decreased. There are now about 300 rental properties in this market.

\subsection{Data Collection Procedure}

This research was conducted for 2 (two) months from December 2020 to January 2021. Primary and secondary data were used for the study. Primary data were obtained from a questionnaire distributed to 156 consumers who purchased agricultural products in $\mathrm{BCMH}$. According to Hair Jr et al. [65], the minimum number of samples in a study should be 100 . Thus, the number of samples in this study has also met the requirement and is suitable for econometric analysis.

A closed-ended questionnaire consisting of two sections was used for the present study: Section 1 included demographic information about the respondents, while Section 2 included questions about market information. Section 1 consisted of the respondent's profile, including age, gender, education, distance between home and market, and nationality. Section 2 included the source of market information, mobile phone and social media ownership, and social interaction with others (see Table 1).

Table 1 . The primary data types collected in this study.

\begin{tabular}{ccc}
\hline Symbol & Variable & Criteria \\
\hline$Y$ & Source of information & $\begin{array}{c}0=\text { from WoM } \\
1=\text { from digital media }\end{array}$ \\
\hline$X_{1}$ & Age & in years \\
\cline { 2 - 3 }$X_{2}$ & Gender & $\begin{array}{c}0=\text { female } \\
1=\text { male }\end{array}$ \\
\hline$X_{3}$ & Education & $\begin{array}{c}0=\text { secondary school } \\
1=\text { bachelor } \\
\text { higher than bachelor }\end{array}$ \\
\hline$X_{4}$ & Mobile phone ownership & $\begin{array}{c}0=\text { yes } \\
1=\text { not }\end{array}$ \\
\hline
\end{tabular}


Table 1. Cont.

\begin{tabular}{ccc}
\hline Symbol & Variable & Criteria \\
\hline$X_{5}$ & $\begin{array}{r}\text { Direct social interaction with other } \\
\text { people every day }\end{array}$ & $\begin{array}{l}0=\text { yes } \\
1=\text { no }\end{array}$ \\
\hline$X_{6}$ & Social media ownership & $\begin{array}{l}0=\text { yes } \\
1=\text { not }\end{array}$ \\
\hline$X_{7}$ & Distance & $\begin{array}{c}0=\text { close }(1-10 \mathrm{~km}) \\
\text { far (more than } 10 \mathrm{~km})\end{array}$ \\
\hline$X_{8}$ & Nationality & $\begin{array}{c}0=\text { Hungarian } \\
1=\text { non-Hungarian }\end{array}$ \\
\hline
\end{tabular}

The population in this study was consumers who purchased agricultural products in BCMH. The respondents in this research were selected using a convenience method. The sample was drawn from a group of participants who were easy for the researcher to reach. The main criteria of the sampling method were availability and willingness to participate [66]. While conducting this study, researchers used masks and followed health protocols, social distancing, and Covid-19 prevention guidelines. Secondary data were collected from the internet on $\mathrm{BCMH}$ profile and promotion.

\subsection{Data Analysis}

The binary logistic model was used to find the determinants of the use of an information source by consumers who purchased something at $\mathrm{BCMH}$.

$$
Y=\beta_{0}+\beta_{1} X_{1}+\beta_{2} X_{2}+\beta_{3} X_{3}+\beta_{4} X_{4}+\beta_{5} X_{5}+\beta_{6} X_{6}+\beta_{7} X_{7}+\beta_{8} X_{8}+e
$$

The binary logistic model tends to solve the constraints of the linear probability model, i.e., the probability can be less than zero or greater than one, and the partial effects of the explanatory variable are constant [67]. This model is based on the cumulative logistic probability function, and the dependent variable is the probability of an event having a specific value from the explanatory variable [68]. The binary logistic model may also be an alternative when the data do not have a normal distribution and mutual covariance [69].

The binary logistic model is used to determine the independent variables and their interactions with the dependent variable. This model describes and predicts the likelihood for the combination of the independent variable with the dependent variable [70]. This model is used to constrain probabilities to the intervals $(0,1)$. If there is a function $\mathrm{L}$, there is a likelihood [71]

$$
\gamma(1)=\frac{e^{-1}}{\left(1+e^{-1}\right)^{2}},-\infty<1<\infty
$$

The likelihood has the cumulative distribution function:

$$
\Lambda(\mathrm{l})=\mathrm{P}[\mathrm{L} \leq \mathrm{l}]=\frac{1}{1+e^{-1}}
$$

Based on Table 1, the logistic probability in this study that the observed value y takes the value 1 is as follows:

$$
\begin{aligned}
\mathrm{p}= & \mathrm{P}\left[\mathrm{L} \leq \beta_{0}+\beta_{1} \mathrm{X}_{1}+\cdots \ldots+\beta_{8} \mathrm{X}_{8}\right] \\
= & \Lambda\left(\beta_{0}+\beta_{1} \mathrm{X}_{1}+\cdots \ldots+\beta_{8} \mathrm{X}_{8}\right) \\
& =\frac{1}{1+\mathrm{e}^{-\left(\beta_{0}+\beta_{1} \mathrm{X}_{1}+\cdots \ldots+\beta_{8} \mathrm{X}_{8}\right)}}
\end{aligned}
$$


Therefore, the probability that $\mathrm{y}=1$ can be written as

$$
\begin{gathered}
\mathrm{p}=\frac{1}{1+\mathrm{e}^{-\left(\beta_{0}+\beta_{1} X_{1}+\cdots \ldots+\beta_{8} \mathrm{X}_{8}\right)}} \\
=\frac{\exp \left(\beta_{0}+\beta_{1} \mathrm{X}_{1}+\cdots \ldots+\beta_{8} \mathrm{X}_{8}\right)}{1+\exp \left(\beta_{0}+\beta_{1} \mathrm{X}_{1}+\cdots \ldots+\beta_{8} \mathrm{X}_{8}\right)}
\end{gathered}
$$

The probability that $\mathrm{y}=0$ is

$$
1-p=\frac{1}{1+\exp \left(\beta_{0}+\beta_{1} X_{1}+\cdots \ldots+\beta_{8} X_{8}\right)}
$$

Next, the Wald test is performed, which is similar in principle to the $t$-test.

$t_{s t a t}=\frac{\beta_{k}-c}{\operatorname{se}\left(\beta_{k}\right)}$ and it is compared with $t_{\text {table }}: t(N-K)$ where $\beta_{k}$ is the logit parameter estimator, $\mathrm{N}$ is the sample size, and $\mathrm{K}$ is the number of parameters to be estimated. Apart from $\mathrm{t}$-Wald, the significance of each variable can be detected from the $p$-value. The variable in this research was significant if the $p$-value was less than 0.10 .

Last, odds and odds ratios were used to interpret the coefficients in the binary logistics model. When the independent variables are binary, that is, coded as 0 and 1 , the odds ratio can be written as follows:

$$
\Omega(0,1)=\frac{\mathrm{P}(1) /[1-\mathrm{P}(1)]}{\mathrm{P}(0) /[1-\mathrm{P}(0)]}
$$

\section{Results}

\subsection{Characteristic of Respondents}

Figure 2 shows that majority of consumers received information about SMEs in BCMH from WoM (86\%) and the rest from digital media (14\%). Family (parents and wife or husband), friends at work or school, and neighbors were the sources of information for WoM. The type of information consumers receive was related to the location, quality and price of the product, friendliness of the seller, and others. Some consumers also received information about SMEs in this market through mobile phones and computers connected to the internet. There is an official website and a number of articles on the internet that report about the BCMH. Social media such as YouTube, Facebook, Twitter, and Pinterest also provide information about this market.

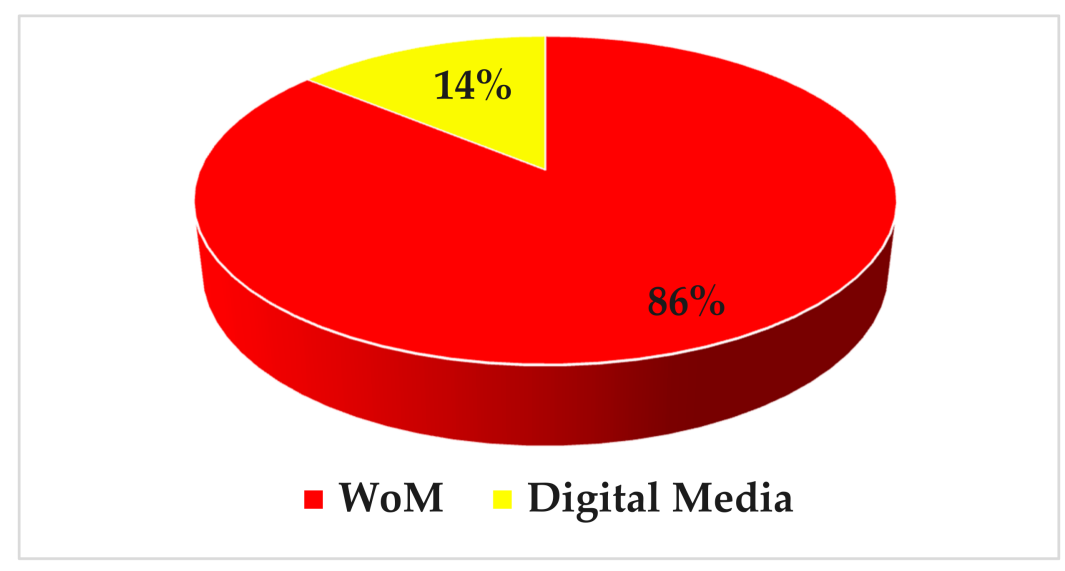

Figure 2. Source of information. WoM, word-of-mouth.

Respondents' trust in BCMH information varied widely (see Figure 3). Most consumers who used WoM trusted the information in the range of $81-90 \%$ and $91-100 \%$. This is because consumers received information from others who had a close relationship with them. Consumers who received information from digital media usually still had doubts 
about this information. They assumed that information from digital media was too much and did not correspond to the facts. Moreover, it turned out that the respondents who received information from digital media were mostly non-Hungarians. They did not know the conditions in Hungary. Therefore, they naturally did not trust this information.

As far as age is concerned, consumers in BCMH were mostly 31-50 years old (see Figure 4). They bought meat, vegetables, and fruits for their daily needs. However, some of them also had tourism motives. This is because $\mathrm{BCMH}$ has become one of the destinations for tourists visiting Hungary.

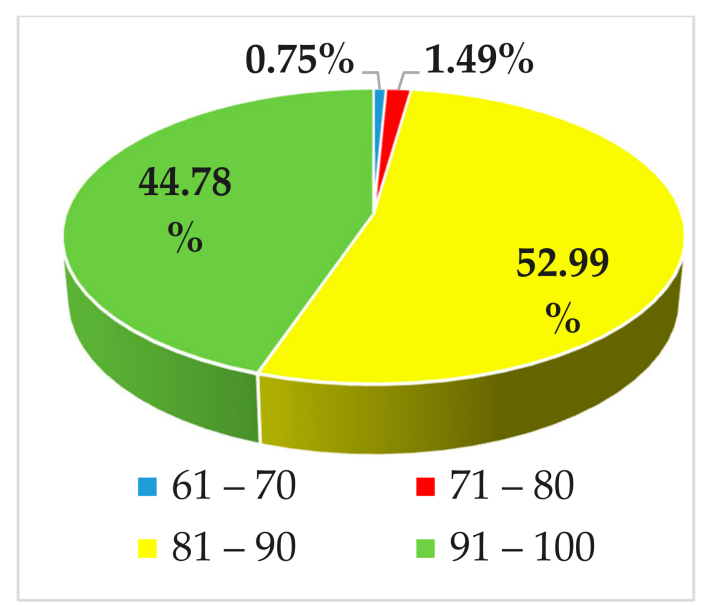

(a)

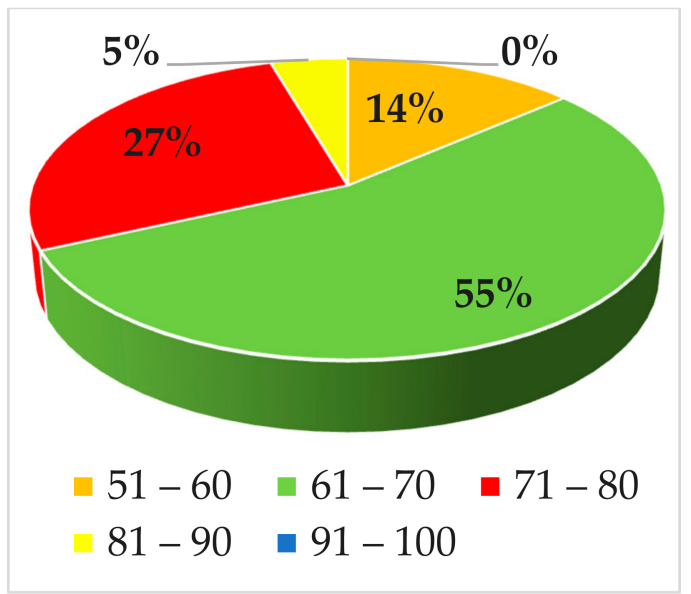

(b)

Figure 3. The level of consumer trust in $\operatorname{WoM}(\mathbf{a})$ and digital media (b).

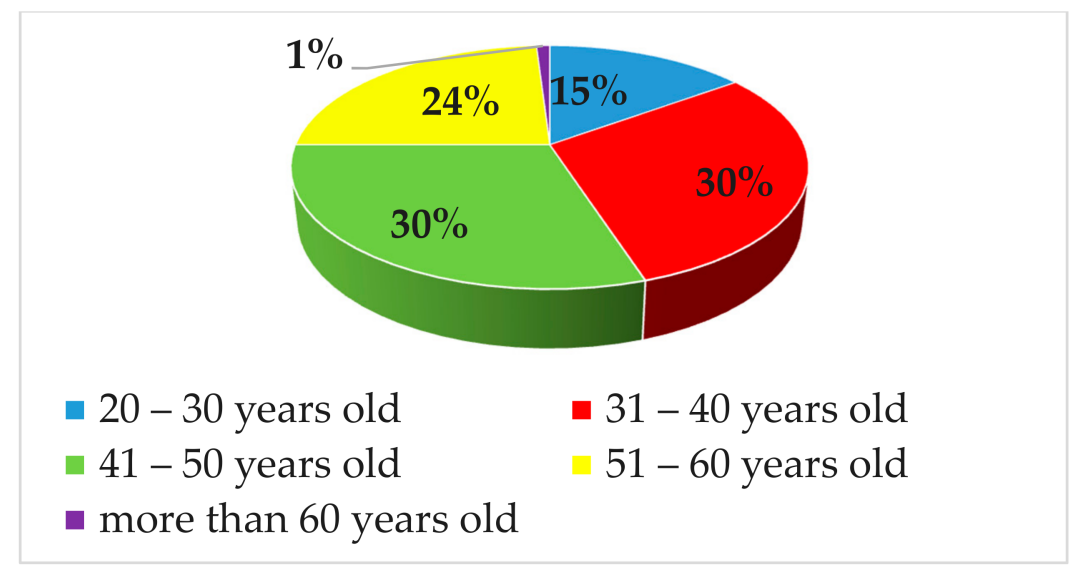

Figure 4. Characteristics of the respondent based on age.

Regarding gender, $84 \%$ of $\mathrm{BCMH}$ consumers were female, while the rest were male (see Figure 5). Females generally had stronger preferences in determining and fulfilling household nutrition than males. They took responsibility for purchasing food for their household needs. 


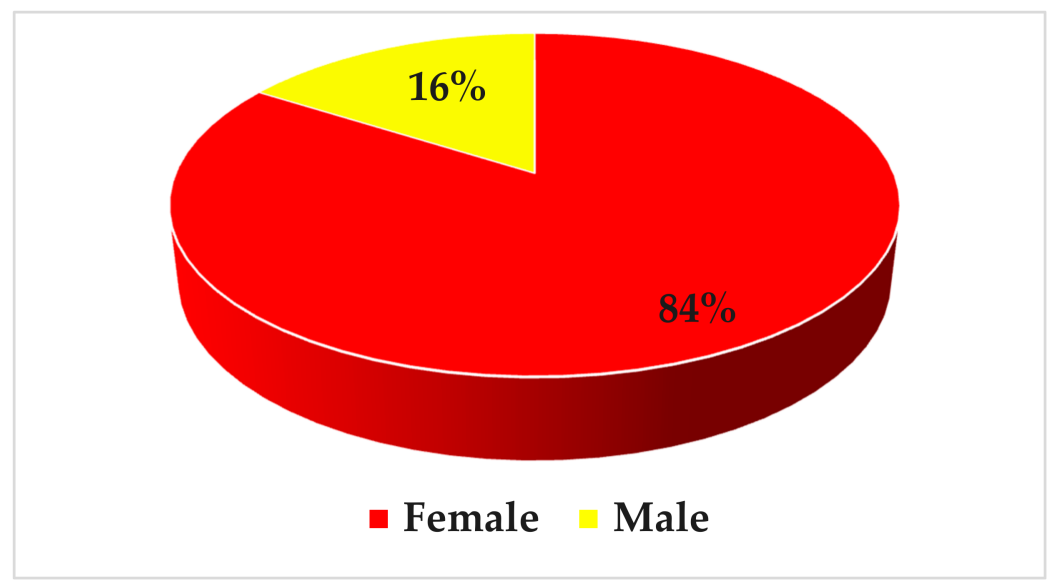

Figure 5. Characteristics of the respondent based on gender.

Figure 6 shows that the education of BCMH consumers consisted of secondary school $(76 \%)$, bachelor $(17 \%)$, and higher education $(7 \%)$. This is because Hungary has a strong education system, so many of its citizens have completed secondary school or higher. Non-Hungarian consumers were also well educated, as they were currently studying in Hungary. The non-Hungarians who attended BCMH in this study were foreign students, not tourists. This is because the Hungarian Government still enforced border restrictions, so tourists were not allowed to enter.

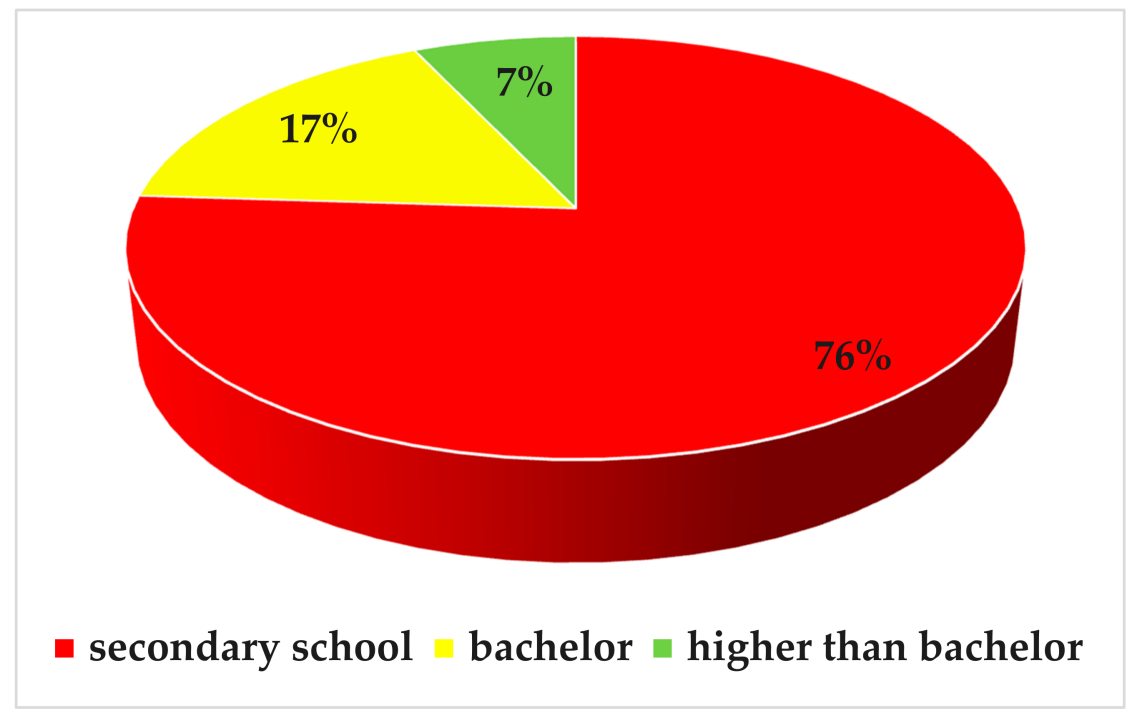

Figure 6. Characteristics of respondents based on education.

The next characteristic, mobile phone ownership, showed that as many as $97 \%$ of consumers owned a mobile phone, and 3\% did not have a mobile phone (see Figure 7). Almost every respondent had at least one mobile phone, and this tool facilitates all aspects of life. Consumers use mobile phones to interact with others through social media. This can be seen in the ownership of social media where $78 \%$ had it while $22 \%$ did not have it (see Figure 8). 


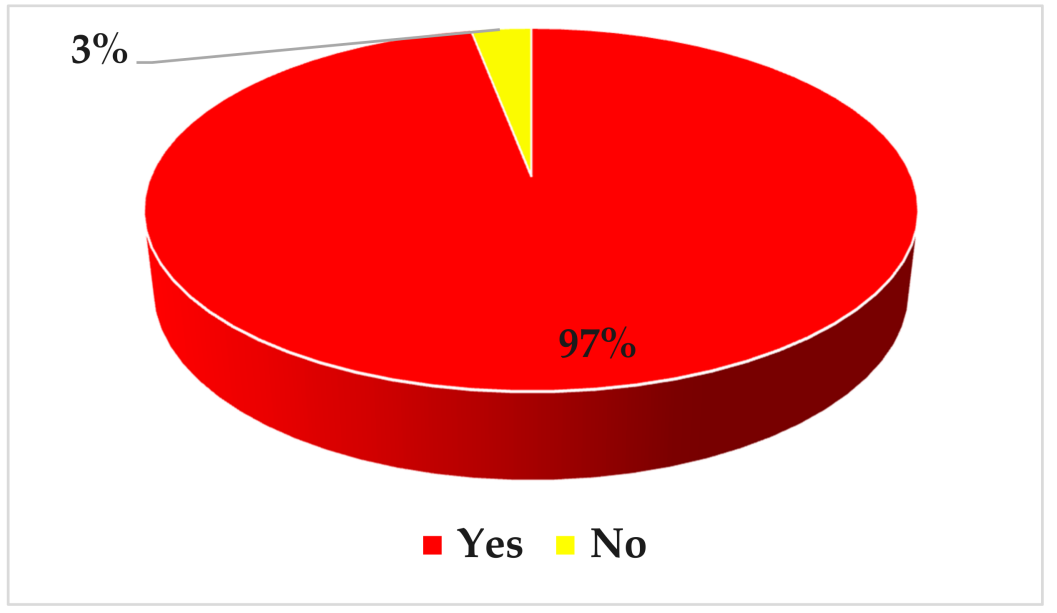

Figure 7. Characteristics of respondents based on mobile phone ownership.

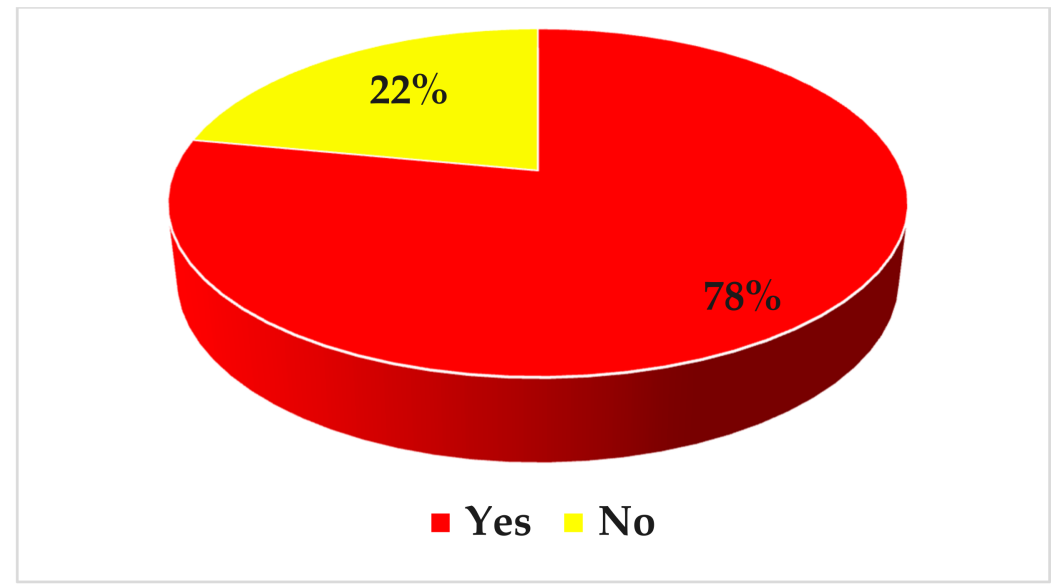

Figure 8. Characteristics of respondents based on social media ownership.

Many consumers (65\%) interacted with other people on a daily basis. They interacted with neighbors and friends at work or school. Conversely, 35\% of consumers did not interact with other people on a daily basis (see Figure 9). In principle, they interacted with other people, but the intensity was lower than that in the previous category of consumers. Almost all consumers lived in the vicinity of the BCMH. However, $3 \%$ of consumers lived more than $10 \mathrm{~km}$ away from the BCMH. They still tried to come to the BCMH because they wanted to shop and travel (see Figure 10). Finally, in terms of nationality, $90 \%$ of consumers were from Hungary, and the rest were non-Hungarian (see Figure 11). The majority of these non-Hungarians were international students. 


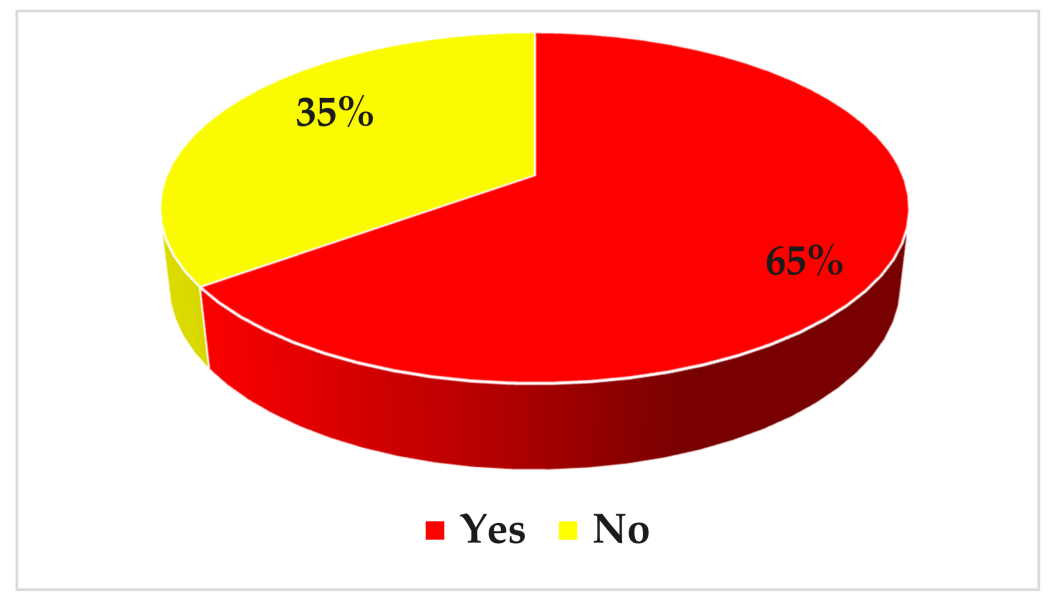

Figure 9. Characteristics of respondents based on direct social interaction with other people every day.

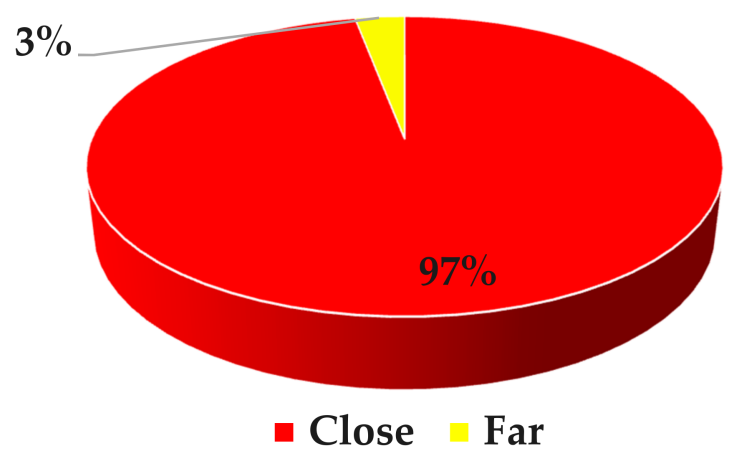

Figure 10. Characteristics of respondents based on distance of their residence from BCMH.

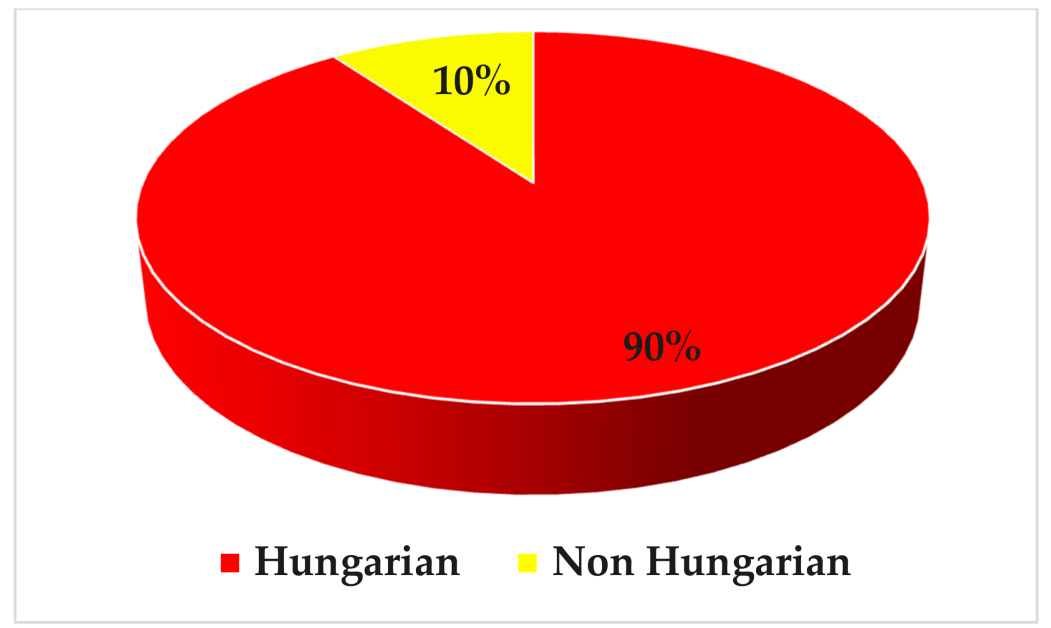

Figure 11. Characteristics of respondents based on nationality.

4.2. Determinant Factors of the Source of Consumer Information in the Agricultural Local Market of Hungary

The estimated determinants of the source of consumer information for those who bought products in the local agricultural market in Hungary are presented in Table 2. Theoretically, estimation using the binary logistic model did not require the application of multicollinearity, heteroskedasticity, and normality tests [72]. The Nagelkerke R-squared 
result showed that $72 \%$ of the variation in the dependent variable can be explained by the variation in the independent variable. Meanwhile, the $p$-sig of the Hosmer and Lemeshow test was greater than 0.05 , so the model can describe the data well (goodness of fit).

Table 2. Determinants of consumers' use of an information source in the local agricultural market in Hungary.

\begin{tabular}{|c|c|c|c|c|c|}
\hline Variable & B & Std. Error & Wald & Sig & $\operatorname{Exp}(B)$ \\
\hline $\mathrm{Y}$ & -6.833 & $26,668.105$ & 0.000 & 1.000 & 0.001 \\
\hline$X_{1}$ & -0.152 & 0.060 & 6.419 & $0.011^{(*)}$ & 0.859 \\
\hline$X_{2}$ & 0.158 & 1.282 & 0.015 & $0.902^{\mathrm{ns}}$ & 1.171 \\
\hline$X_{3}$ & 1.182 & 0.709 & 2.781 & $0.095^{(* *)}$ & 3.262 \\
\hline $\mathrm{X}_{4}$ & -12.642 & $17,710.171$ & 0.000 & $0.999 \mathrm{~ns}$ & 0.001 \\
\hline$X_{5}$ & 1.673 & 0.900 & 3.456 & $0.063^{(* *)}$ & 5.329 \\
\hline$x_{6}$ & -3.021 & 4.243 & 0.507 & $0.476^{\mathrm{ns}}$ & 0.049 \\
\hline$x_{7}$ & 17.388 & $19,938.348$ & 0.000 & $0.999^{\mathrm{ns}}$ & $35,600,742.895$ \\
\hline $\mathrm{X}_{8}$ & 3.914 & 1.899 & 4.247 & $0.039^{(*)}$ & 50.082 \\
\hline \multicolumn{2}{|c|}{ Nagelkerke R-squared } & 0.720 & & & \\
\hline \multicolumn{2}{|c|}{ Hosmer and Lemeshow sig test } & 0.996 & & & \\
\hline
\end{tabular}

From the estimation results in Table 2, it can be seen that there were four significant variables, namely age, education, direct social interaction, and nationality. Other variables, including gender, mobile phone and social media ownership, and distance from residence to $\mathrm{BCMH}$, had no impact on the dependent variable. This can be seen from the $p$-value (sig), where the variable would be significant if the value is less than 0.10 . Next, the coefficient exp beta (B) can be used to determine how much impact the independent variable has on the dependent variable. This is defined as the ratio of the probability of an event occurring to the probability of it not occurring [70].

Age had a significant impact on consumers' use of an information source with a 5\% level of error. Consumers were 0.859 times more likely to use information on WoM than they were to use information on digital media if they were older.

Conclusion: accept Hypothesis 1, or age has a significant impact on consumers' use of an information source.

Gender had no impact on the dependent variable. It was found to be not statistically significant $(p>0.10)$. This indicates that gender does not increase or decrease the likelihood of consumers using an information source.

Conclusion: reject Hypothesis 2, or gender had no significant impact on consumers' use of an information source.

Education had a significant impact on the use of an information source at the $10 \%$ level of error. Someone who is educated is 3.262 times more likely to use information via digital media than to use information via WoM.

Conclusion: accept Hypothesis 3, or education has a significant impact on consumers' use of an information source. 
Mobile phone ownership had no impact on the dependent variable. It was considered statistically insignificant $(p>0.10)$. This implies that mobile phone ownership would neither increase nor decrease consumers' willingness to use an information source.

Conclusion: reject Hypothesis 4, or owning a mobile phone had no significant impact on consumers' use of an information source.

Direct social interaction had a significant effect on consumers' use of an information source at the $10 \%$ level of error. When consumers rarely interact, they are 5.329 times more likely to use information from digital media than they are to use information through WoM.

Conclusion: accept Hypothesis 5, or direct social interaction has a significant impact on consumers' use of an information source.

Social media ownership had no impact on the dependent variable. It was not considered statistically significant $(p>0.10)$. This indicates that social media ownership neither increases nor decreases the likelihood of consumers using an information source.

Conclusion: reject Hypothesis 6, or social media ownership did not significantly influence consumers' use of an information source.

Distance from home to $\mathrm{BCMH}$ had no impact on the dependent variable. It was found to be statistically insignificant $(p>0.10)$. This means that distance from residence to $\mathrm{BCMH}$ neither increases nor decreases the likelihood of consumers using an information source.

Conclusion: reject Hypothesis 7, or distance had no significant effect on consumers' use of an information source.

Nationality had a significant impact on consumers' use of an information source with a $5 \%$ level of error. Consumers are 50.082 times more likely to use information on digital media than they are to use information on WoM if they are foreigners or non-Hungarians.

Conclusion: accept Hypothesis 8, or nationality has a significant impact on consumers' use of an information source.

\section{Discussion}

\subsection{Word-of-Mouth or Digital Media in Agricultural SMEs}

The first variable that has a significant impact on the use of the type of information media is age. Older people would choose WoM and have a lower acceptance to use digital media. Several studies often show a tendency that older people have a lower acceptance towards current technologies. This may be because their cognitive abilities have decreased, and the difficulty of using modern technological devices has increased [73,74]. Becic et al. [75] concluded that they still act conservatively and avoid the potentially harmful consequences of new technologies.

Older people use digital media only to read news and other interesting things, to connect with family members and acquaintances, and to seek additional information [76]. However, the most important thing is that they like to talk face-to-face to receive information [77]. This is understandable because, from the consumer's point of view, WoM is closely related to the credibility of information [78]. Other findings are consistent with this research, i.e., older people tend to use WoM because they have difficulty using digital media and receive more accurate information from people with close ties.

This research also shows that young people like information in digital media. They feel more comfortable and satisfied with complicated ICTs [79]. This is because it is easier for young people to learn modern technologies. Their interest is also higher than that of 
older people because young people see the benefits of using digital media [20]. In this study, young consumers indicated that it was easy to find SMEs information on digital media (YouTube) and find consumer satisfaction ratings. This rating is one of the considerations that consumers need to visit and shop at BCMH.

Education is the second variable that has a significant impact on the use of the type of information media. Almost the same as young people, educated people are also interested and involved in using digital media [80]. There are many assumptions that educated people are more willing to accept technology and have an expanded ability to understand it [81]. This is because they easily learn and understand the benefits of digital media [20,79]. In other research, Zhu et al. [81] and Mumporeze and Prieler [82] argue that lower levels of education are still a major barrier for non-digital media users. They prefer to communicate face-to-face with other people [77]. It is better for them to receive a thorough explanation of the information. They also have more trust in information conveyors as they meet face-to-face. This supports the findings of this study by ensuring that those with secondary education receive more information from WoM, while those with a bachelor's degree and higher education receive information from digital media.

The third variable that has a significant impact on the use of the type of information media is direct social interaction. Consumers seek information from digital media when they rarely interact or receive information from others about SMEs in $\mathrm{BMCH}$. They frequently use digital media to seek online feedback from other consumers. Evidence shows that these reviews have a positive impact on consumers' decisions and are more accurate than marketers' information [83]. Meanwhile, consumers, often interacting socially, physically, or otherwise, share information and opinions about the market. This has a huge impact on marketing and can be a valuable tool for marketers [84]. It should be noted that social interaction works optimally when the information or knowledge gap between consumers is not too large and the efficiency of interpersonal information exchange is very high [85].

Nationality is the last variable that has a significant impact on the use of the media type of media information. Non-Hungarians would have a greater chance of receiving BCMH information from digital media. This is consistent with studies by Vázquez et al. [80] who claimed that immigrants or foreigners use ICT more because they have a greater need to communicate than natives. Each of the consumers in this study comes from countries with strong digital literacy, such as Kazakhstan, India, Jordan, and Turkey [19]. Meanwhile, consumers from low digital literacy countries continue to use digital technologies due to limited social interactions with Hungarians and language barriers. They look for information in digital media so they can easily learn about SMEs in BCMH.

Gender does not significantly influence the use of the type of information media. These results suggest that there is little difference in access to information between women and men. This differs significantly from the findings of studies in developing countries where differences in gender would affect differences in access to information. Women would have limited access to various sources of information, both from WoM and digital media [82]. In addition, both men and women use media to learn about BCMH.

Mobile phone ownership does not significantly impact the use of the type of information media. Logically, mobile phone ownership would increase the likelihood of consumers obtaining and selecting information from digital media, but this was not the case in this study. This finding is consistent with the results of Kawakami and Parry's study [78], in which mobile phone ownership does not always increase the prevalence of digital media use. Almost all consumers in this study have mobile phones, but SMEs in BCMH information was inherited from their families. However, there are still consumers who use their mobile phones to find information about SMEs in BMCH. Thus, the use of either media, WoM or digital media, in this study would not be influenced by mobile phone ownership.

Social media ownership does not significantly influence the use of the type of information media. This study hopes that social media ownership increases the possibility of consumers receiving $\mathrm{BCMH}$ information from digital media. The ease of using social media 
makes it easy for people to search for market information [40]. However, consumers in this study receive information from both WoM and digital media. In reality, consumers might be more interested in using WoM because BCMH information is less attractive on social media. Moreover, the information about this market in social media is presented in Hungarian, so non-Hungarian consumers do not understand it. This condition was the same as in the study by Zamarreño-Aramendia et al. [86], who found that many parties do not make optimal use of social media as an open innovation. Nevertheless, marketers can use social media to communicate product information, interact with consumers, and collect feedback from consumers for business improvement and innovation.

Distance has no significant effect on the use of the type of information media. This finding contradicts the study of Steffes and Burgee [81], who claimed that distance had an impact on technology use. The further away the person's home from the market, the more likely they are to use digital media. In this study, many consumers receive WoM information even though their residence is far from $\mathrm{BCMH}$. On the other hand, there are consumers who live near the $\mathrm{BCMH}$ but receive information through digital media. This is because they are non-Hungarians who seek a lot of information through digital media.

Regarding open innovation, our study shows that modern ICTs are not always accepted by all citizens in developed countries. WoM is still very relevant to promote SME products in Hungary. These media create consumers' trust in marketers. However, WoM has a weakness, which is that marketers rarely receive direct feedback from consumers and cannot react quickly when consumers have an unfavorable opinion about their products. This will hinder the achievement of the fifth point of Model Building of Cultivating Forward Neighborhood Rectangular Concept, which is to connect with the customer [3]. Disappointed consumers are likely to stop shopping at SMEs and pass on their dissatisfaction to others. Meanwhile, SMEs are unaware of this situation and receive almost no feedback from consumers. As a result, SMEs will lose customers and their businesses will go bankrupt.

Indeed, the risk of bankruptcy can be avoided if SMEs are able to adopt open innovation, especially the use of ICTs. The third point of Model Building of Cultivating Forward Neighborhood Rectangular Concept has previously promoted the use of technological systems. It has been found to be useful for consumers in this study. Digital media can connect social and economic progress between marketers and consumers. However, this study also shows that mobile phones and social media were not used optimally. This is due to the language barrier, as social media mostly advertises BCMH in Hungarian. Therefore, SMEs in Hungary need to provide information in English. This is also an open innovation that can enable smooth operation of the value and provide many benefits to market participants.

\subsection{The Way of Open Innovation in Agricultural SMEs}

The food industry is faced with many challenges, so open innovation in this field is very dynamic. et al. This can be seen in the ever-changing consumer choices and market demand [87]. Jack et al. [88] listed open innovations in the food industry including new production, processing and waste technologies (new machinery or specialized equipment), digitization of the sector (IT system), production management techniques (an increased focus on lean manufacturing, continuous improvement, and business performance targets), and management skills.

Our research shows that open innovation in the food industry is very dynamic, especially the digitization of information. There are consumers who currently prefer digital media as a medium to promote agricultural SMEs. However, there are more consumers who favor the use of WoM in the agri-food industry. This is certainly surprising since our study was conducted in a developed country where all life processes are based on advanced technologies. Clearly, SMEs need to satisfy the desire of these two consumer groups in order to maintain strong relationships with them. This would play an important role in generating open innovation [89]. 
The open innovation chosen by each food industry may differ as it adapts to its own resources and the surrounding market environment. Yun et al. [90] provided an example of the differences in open innovation among three restaurants from different regions. First, restaurants in Naples, Italy, focus on open innovation in terms of variety of food ingredients and menu, excellent service and quick response time, and creative and fantastic decorations. Second, a restaurant in Gyeongju, South Korea, conducts open innovation by offering diverse food ingredients, establishing good communication, providing convenient facilities, and setting up platforms to promote products. Finally, a restaurant in Phnom Penh, Cambodia, focuses on providing entertainment for customers and menu variations.

Despite their different approaches to innovation, all restaurants share the same goals: to create customer and market information and promote communication with customers, suppliers, and other and other collaborators; and create combinative innovation and customer self-creation. This is what every participant in the food industry must have in order to survive the fierce and open innovation competition. Therefore, the food industry must embrace and become familiar with the culture of open innovation dynamics [90].

In connection with our study, the first source of the concept of open innovation dynamics in the food industry begins with the emergence of a new combination or innovation by food entrepreneurs. This happens at the micro level and will change the existing order, also at the macro level, so that new products or services, new markets, new processes, new organizations, or new materials appear in the food industry. The next source of open innovation dynamics is intrapreneurship by employees of existing food companies. They look for opportunities within existing food organizations with an entrepreneurial spirit. The result is the development of new business areas, increased innovation, self-renewal, or proactivity of existing large companies that rely primarily on closed innovation but pursue an open innovation strategy. The final source of open innovation dynamics is organizational entrepreneurship by the firm itself. This innovation will promote evolutionary changes in the food industry system. They implement mechanisms for "culture articulation and reinforcement" such as organizational structures, systems, and procedures, as well as formal statements of organizational values, philosophies, or beliefs, so that they can play a role in shaping the culture for evolutionary change in their company and the food and beverage industry [91].

In our research it is clear that there is a gap between SMEs and consumers, e.g., consumers want digital media to be presented in English but SMEs are not yet able to do this. If it is related to any of these problems, it can be said that the concept of open innovation dynamics is not going well. Thus, steps are needed to reinvent $R \& D$ in an open innovation ecosystem in the food industry. For this, food SMEs and companies need (1) a clear strategy that involves all participants in the food industry value chain and internal experts; (2) a focus on value chain and consumer-centric innovation; (3) a leader with a strong vision that offers solutions to various problems, promotes cultural change, and provides tools or smart applications to support co-innovation; (4) a measure of innovation capability (qualitative, quantitative, baseline) that should be linked to key performance indicators, reward mechanisms, and benchmarking; (5) support for all stakeholders in innovation development and reward or compensation; and (6) academics to teach system reform and increase student participation, industry role, and social responsibility [92].

\section{Conclusions, Implications, Limitations, and Future Research \\ 6.1. Conclusions}

Our results are in line with findings of the classic theory of "two stage communication" of Lazersfeld et al. [93], but we have generalized this result in the digital era and were able to prove that word-of-mouth (WoM) is an important source and booster of information, even in years of digital communication. Consumers have trust in WoM information, but the reach of information is tighter than digital media. WoM is most commonly used for elderly peoples. 
The role of digital media seems to be more to reach out to consumers with distinctive characteristics, such as those who are educated, or who are rarely socially interact, or who are foreigners. Consumers use social media, Facebook, and Twitter to receive information about SMEs in BCMH. However, this information can only be interpreted by local people because it is delivered in Hungarian, not in English, and non-Hungarian citizens do not receive complete and accurate information.

Finally, the results of this study contribute to the progress of consumer behavior theory in developing countries. Demographic factors (age, education, and nationality) and social interaction have a significant impact on consumers' evaluation of market information. Both factors have an even greater effect than the technological factor (ownership of mobile phones and social media). For the development of open innovation, especially information mobility, SMEs need to provide products in international languages, especially English.

\subsection{Implications}

SMEs in Hungary need to actively disseminate information in digital media through English and social media (YouTube, Facebook, Twitter, etc.). In this study, consumers found information on YouTube that was not presented by SME managers. SMEs also need to develop two-way connectivity such as e-WOM to provide complete information. e-WoM is a perfect way to merge traditional marketing strategies (WoM) with digital marketing strategies. Moreover, the use of digital media will increase while there are still many consumers who trust information from WoM.

In addition, SMEs should maintain consumer trust so that they will shop again and be willing to share information about SMEs. In this way, SMEs maintain the quality of products and services to satisfy consumers. This activity can also anticipate the possibility that people who are not familiar or comfortable with digital media may end up trusting WoM more.

In the context of food industry development, we recommend an open innovation dynamic at both the micro and macro levels, involving all participants in the value chain. Each actor has its own role. SMEs and entrepreneurs innovate at the micro level, firms at the macro level. Consumers, individuals, and experts provide suggestions for value chain improvement and consumer-driven innovation. Academics lead education, which stimulates innovations. Finally, the government regulates and rewards the development of innovations.

In developing their communication strategy, SMEs need to determine such groups of local opinion leaders, who could be their "ambassadors", influencing the behavior and choice of their acquaintances and family members. It is necessary to identify who could be such authentic persons, who have a relatively good understanding of food procurementrelated questions. In this way, there is a possibility to fine-tune the targeted marketing efforts of SMEs.

\subsection{Limitations}

This study was limited because it was conducted during the Covid-19 pandemic, which prevents the researchers from meeting and communicating with many of the respondents over a long period of time. In addition, the existence of border restrictions by the Hungarian Government prevents tourists or foreigners from entering the country. This leads to the fact that the number of buyers in SMEs in this study were mainly locals, and the results of this study may not be optimal or ideal. For this reason, further studies can be conducted under normal circumstances to assess the socio-economic conditions in the Hungarian market or in a broader region, such as Central Europe.

This also contributed to the convenience sampling method used in this study. In reality, under normal conditions, the researchers would use a purposive method to find more non-Hungarian respondents. 


\subsection{Future Research}

The results of this study provide opportunities for other investigators to conduct research from a quality perspective, such as prioritizing consumer needs. As a result, SMEs will be able to determine what actions should be taken to meet consumer needs through quality business processes and continuous improvement of overall business processes integrated with the provision of appropriate marketing information through digital media.

Another possible area of research is the impact of the e-WOM model on the market. Steffes and Burgee [94] found that consumer decisions are more influenced by e-WOM information than by face-to-face conversation with friends (WOM). This should also overcome one of the findings of this study, namely low consumer trust in digital media information.

Author Contributions: Conceptualization, T.W. and A.D.N.; methodology, T.W. and A.D.N.; software, A.D.N.; validation, T.W., A.D.N. and C.B.I.; formal analysis, A.D.N.; investigation, T.W.; resources, T.W.; data curation, T.W.; writing-original draft preparation, T.W. and A.D.N.; writingreview and editing, A.D.N.; visualization, A.D.N.; supervision, Z.L., A.D. and C.B.I.; project administration, T.W.; funding acquisition, T.W. All authors have read and agreed to the published version of the manuscript.

Funding: This research received no external funding.

Data Availability Statement: The data presented in this study are available on request from the corresponding author.

Acknowledgments: We would like to thank, first, the reviewers who gave us suggestions on how to develop this article. Secondly, to the managers, consumers and sellers of Budapest Central Market Hall, who gave the opportunity to collect data and were willing to complete the questionnaire.

Conflicts of Interest: The authors declare no conflict of interest.

\section{References}

1. Razumovskaia, E.; Yuzvovich, L.; Kniazeva, E.; Klimenko, M.; Shelyakin, V. The Effectiveness of Russian Government Policy to Support SMEs in COVID-19 Pandemic. J. Open Innov. Technol. Mark. Complex. 2020, 6, 160. [CrossRef]

2. Prasanna, R.P.I.R.; Jayasundara, J.M.S.B.; Gamage, S.K.N.; Ekanayake, E.M.S.; Rajapakshe, P.S.K.; Abeyarathne, G.A.K.N.J. Sustainability of SMEs in the Competition: A Systemic Review on Technological Challenges and SME Performance. J. Open Innov. Technol. Mark. Complex. 2019, 5, 100. [CrossRef]

3. Yun, J.J.; Zhao, X. Business Model Innovation through a Rectangular Compass: From the Perspective of Open Innovation with Mechanism Design. J. Open Innov. Technol. Mark. Complex. 2020, 6, 131. [CrossRef]

4. Wielki, J. Analysis of the Role of Digital Influencers and Their Impact on the Functioning of the Contemporary On-line Promotional System and its Sustainable Development. Sustainability 2020, 12, 7138. [CrossRef]

5. Belanche, D.; Flavian, M.; Perez-Rueda, A. Mobile Apps Use and WOM in the Food Delivery Sector: The Role of Planned Behavior, Perceived Security and Customer Lifestyle Compatibility. Sustainability 2020, 12, 4275. [CrossRef]

6. Godes, D.; Mayzlin, D.; Chen, Y.; Das, S.; Dellarocas, C.; Pleiffer, B.; Libai, B.; Sen, S.; Shi, M.; Verlegh, P. The Firm's Management of Social Interactions. Mark. Lett. 2005, 16, 415-428. [CrossRef]

7. Sun, T.; Youn, S.; Wu, G.; Kuntaraporn, M. Online Word-of-Mouth (or Mouse): An Exploration of its Antecedents and Consequences. J. Comput. Mediat. Commun. 2006, 11, 1104-1127. [CrossRef]

8. Yu, M.; Liu, F.; Lee, J.A. Consumers' Response to Negative Publicity: The Influence of Culture on Information Search and Negative Word-of-Mouth. J. Brand Manag. 2019, 26, 141-156. [CrossRef]

9. King, R.A.; Racherla, P.; Bush, V.D. What We Know and Don't Know about Online Word-of-Mouth: A Review and Synthesis of the Literature. J. Interact. Mark. 2014, 28, 167-183. [CrossRef]

10. Twardzik, M.; Heffner, K. Small Towns and Rural Areas-As Prospective Place of Modern Retail Trade Formats in Poland. Eur. Countrys. 2019, 11, 74-84. [CrossRef]

11. Belyaeva, Z.; Rudawska, E.D.; Lopatkova, Y. Sustainable Business Model in Food and Beverage Industry-A Case of Western and Central and Eastern European Countries. Br. Food J. 2020, 122, 1573-1592. [CrossRef]

12. Abrham, J.; Strielkowski, W.; Vosta, M.; Slajs, J. Factors that Influence the Competitiveness of Czech Rural SMEs. Agric. Econ. Czech 2015, 61, 450-460. [CrossRef]

13. Sebestova, J.; Sroka, W. Sustainable Development Goals and SME Decisions: The Czech Republic vs. Poland. J. East. Eur. Cent. Asian Res. 2020, 7, 39-50. [CrossRef]

14. Massaro, M.; Rubens, A.; Bardy, R.; Bagnoli, C. Antecedents to Export Performance and How Italian and Slovenian SMEs Innovative During Times of Crisis. J. East. Eur. Cent. Asian Res. 2017, 4, 1-22. [CrossRef] 
15. Medve-Bálint, G.; Šćepanović, V. EU Funds, State Capacity and the Development of Transnational Industrial Policies in Europe's Eastern Periphery. Rev. Int. Political Econ. 2020, 27, 1063-1082. [CrossRef]

16. Nyikos, G.; Beres, A.; Laposa, T. Micro-economic Effects of Public Funds on Enterprises in Hungary. Reg. Stud. Reg. Sci. 2020, 7,346-361. [CrossRef]

17. Korab, P.; Pomenkova, J. Financial Crisis and Financing Constraints of SMEs in Visegrad Countries; Verlags-und Herstellungsort: Wien, Austria, 2014; pp. 1-16.

18. European Commission. Annual Report on European SMEs 2018/2019; Executive Agency for Small and Medium-sized Enterprises European Commission: Luxembourg, 2019; pp. 12-144.

19. IMD World Competitiveness Center. IMD World Digital Competitiveness Ranking 2020; IMD World Competitiveness Center: Lausanne, Switzerland, 2021; pp. 15-44.

20. Seifert, A.; Cotton, S.R. In Care and Digitally Savvy? Modern ICT Use in Long-term Care Institutions. Educ. Gerontol. 2020, 46, 473-485. [CrossRef]

21. Toulova, M.; Tuzova, M.; Straka, J. The Aspects of Managing Risks in Connection with the Internationalization of SMEs from Selected Central European Countries. Acta Univ. Agric. Silvic. Mendel. Brun. 2016, 64, 1775-1784. [CrossRef]

22. Tomasevic, I.; Kovačević, D.B.; Jambrak, A.R.; Szendrő, K.; Zotte, A.D.; Prodanov, M.; Sołowiej, B.; Sirbu, A.; Subić, J.; Roljević, S.; et al. Validation of Novel Food Safety Climate Components and Assessment of Their Indicators in Central and Eastern European Food Industry. Food Control 2020, 117, 107357. [CrossRef]

23. Castellano, S.; Ivanova, O. Signaling Legitimacy in Global Contexts: The Case of Small Wine Producers in Bulgaria. Eur. Bus. Rev. 2017, 29, 243-255. [CrossRef]

24. Herdon, M.; Botos, S.; Varallyai, L. Decreasing the Digital Divide by Increasing e-Innovation and e-Readiness Abilities in Agriculture and Rural Areas. Int. J. Agric. Environ. Inf. Syst. 2015, 6, 1-18. [CrossRef]

25. Mateev, M.; Poutziouris, P.; Ivanov, K. On the Determinants of SME Capital Structure in Central and Eastern Europe: A Dynamic Panel Analysis. Res. Int. Bus. Financ. 2013, 27, 28-51. [CrossRef]

26. Kowalska, M. SME Managers' Perceptions of Sustainable Marketing Mix in Different Socioeconomic Conditions-A Comparative Analysis of Sri Lanka and Poland. Sustainability 2020, 12, 659. [CrossRef]

27. Mateev, M.; Anastasov, Y. New Determinants of Growth in Small and Medium Sized Enterprises in Central and Eastern Europe: A Panel Data Analysis. Int. J. Econ. Res. 2012, 9, 113-136.

28. Reidolf, M. Knowledge Networks and the Nature of Knowledge Relationships of Innovative Rural SMEs. Eur. J. Innov. Manag. 2016, 19, 317-336. [CrossRef]

29. Kirtiş, A.; Karahan, F. To Be or Not To Be in Social Media Arena as the Most Cost-Efficient Marketing Strategy After the Global Recession. Procedia Soc. Behav. Sci. 2011, 24, 260-268. [CrossRef]

30. Mukherjee, S. Challenges to Indian Micro Small Scale and Medium Enterprises in the Era of Globalization. J. Glob. Entrep. Res. 2018, 8, 1-19. [CrossRef]

31. Chatterjee, S.; Kumar Kar, A. Why Do Small and Medium Enterprises Use Social Media Marketing and What Is the Impact: Empirical Insights from India. Int. J. Inf. Manag. 2020, 53, 102103. [CrossRef]

32. Konuk, F. The Influence of Perceived Food Quality, Price Fairness, Perceived Value and Satisfaction on Customers' Revisit and Word-of-Mouth Intentions Towards Organic Food Restaurants. J. Retail. Consum. Serv. 2019, 50, 103-110. [CrossRef]

33. Eisingerich, A.; Chun, H.; Liu, Y.; Jia, H.; Bell, S. Why Recommend a Brand Face-to-Face but Not on Facebook? How Word-ofMouth on Online Social Sites Differs from Traditional Word-of-Mouth. J. Consum. Psychol. 2015, 25, 120-128. [CrossRef]

34. Ying, B.; Yao, R. Self-perceived Age and Attitudes toward Marketing of Older Consumers in China. J. Fam. Econ. Issues 2010, 31, 318-327. [CrossRef] [PubMed]

35. Lee, S. Factors Influencing the Social Networking Service User's Value Perception and Word of Mouth Decision of Corporate Post with Special Reference to the Emotional Attachment. Inf. Technol. Manag. 2016, 17, 15-27. [CrossRef]

36. Riquelme, I.P.; Román, S.; Iacobucci, D. Consumers' Perceptions of Online and Offline Retailer Deception: A Moderated Mediation Analysis. J. Interact. Mark. 2016, 35, 16-26. [CrossRef]

37. Rajagopal. Contemporary Marketing Strategy; Palgrave Macmillan: London, UK, 2019; pp. 3-33. [CrossRef]

38. Caiazza, R.; Bigliardi, B. Web Marketing in Agri-food Industry: Challenges and Opportunities. Trends Food Sci. Technol. 2020, 103, 12-19. [CrossRef]

39. Liao, S.; Yang, L. Mobile Payment and Online to Offline Retail Business Models. J. Retail. Consum. Serv. 2020, 57, 102230. [CrossRef]

40. Meilatinova, N. Social Commerce: Factors Affecting Customer Repurchase and Word-of-Mouth Intentions. Int. J. Inf. Manag. 2021, 57, 102300. [CrossRef]

41. Kim, E.; Libaque-Saenz, C.F.; Park, M. Understanding Shopping Routes of Offline Purchasers: Selection of Search-channels (Online vs. Offline) and Search-platforms (Mobile vs. PC) Based on Product Types. Serv. Bus. 2018, 13, 305-338. [CrossRef]

42. Moon, Y.; Armstrong, D. Service Quality Factors Affecting Customer Attitudes in Online-to-Offline Commerce. Inf. Syst. E-Bus. Manag. 2018, 18, 1-34. [CrossRef]

43. Chmielarz, W. Study of Smartphones Usage from the Customer's Point of View. Procedia Comput. Sci. 2015, 65, 1085-1094. [CrossRef] 
44. Voropanova, E. Conceptualizing Smart Shopping with a Smartphone: Implications of the Use of Mobile Devices for Shopping Productivity and Value. Int. Rev. Retail Distrib. Consum. Res. 2015, 25, 529-550. [CrossRef]

45. Park, J.; Han, S.H. Defining User Value: A Case Study of a Smartphone. Int. J. Ind. Ergon. 2013, 43, 274-282. [CrossRef]

46. Rezabakhsh, B.; Bornemann, D.; Hansen, U.; Schrader, U. Consumer Power: A Comparison of the Old Economy and the Internet Economy. J. Consum. Policy 2006, 29, 3-36. [CrossRef]

47. Fuentes, C.; Svingstedt, A. Mobile Shopping and the Practice of Shopping: A Study of How Young Adults Use Smartphones to Shop. J. Retail. Consum. Serv. 2017, 38, 137-146. [CrossRef]

48. Marchi, R. With Facebook, Blogs, and Fake News, Teens Reject Journalistic "Objectivity". J. Commun. Inq. 2012, 36, $246-262$. [CrossRef]

49. Tandoc, E.; Lim, Z.; Ling, R. Defining “Fake News” A Typology of Scholarly Definitions. Digit. J. 2018, 6, 137-153. [CrossRef]

50. Yang, R.; Che, T. Do Social Ties Matter for Purchase Frequency? The Role of Buyers' Attitude Towards Social Media Marketing. Comput. Hum. Behav. 2020, 110, 106376. [CrossRef]

51. Khwaja, M.; Zaman, U. Configuring the Evolving Role of ewom on the Consumers Information Adoption. J. Open Innov. Technol. Mark. Complex. 2020, 6, 125. [CrossRef]

52. Del Vicario, M.; Bessi, A.; Zollo, F.; Petroni, F.; Scala, A.; Caldarelli, G.; Stanley, E.; Quattrociocchi, W. The Spreading of Misinformation Online. In Proceedings of the National Academy of Sciences, Maribor, Slovenia, 19 January 2016; Perc, M., Ed.; United States National Academy of Sciences: Washington, DC, USA, 2016. [CrossRef]

53. Zollo, F.; Bessi, A.; Del Vicario, M.; Scala, A.; Caldarelli, G.; Shekhtman, L.; Havlin, S.; Quattrociocchi, W. Debunking in a World of Tribes. PLoS ONE 2017, 12, e0181821. [CrossRef]

54. Talwar, S.; Dhir, A.; Kaur, P.; Zafar, N.; Alrasheedy, M. Why Do People Share Fake News? Associations between the Dark Side of Social Media Use and Fake News Sharing Behavior. J. Retail. Consum. Serv. 2019, 51, 72-82. [CrossRef]

55. Visentin, M.; Pizzi, G.; Pichierri, M. Fake News, Real Problems for Brands: The Impact of Content Truthfulness and Source Credibility on Consumers' Behavioral Intentions Toward the Advertised Brands. J. Interact. Mark. 2019, 45, 99-112. [CrossRef]

56. Domenico, G.D.; Sit, J.; Ishizaka, A.; Nunan, D. Fake News, Social Media and Marketing: A Systematic Review. J. Bus. Res. 2021, 124, 329-341. [CrossRef]

57. Hu, H.; Wang, L.; Jiang, L.; Yang, W. Strong Ties Versus Weak Ties in Word-of-Mouth Marketing. Brq Bus. Res. Q. 2019, 22, 245-256. [CrossRef]

58. Hult, G.T.M.; Sharma, P.N.; Morgeson, F.V.; Zhang, Y. Antecedents and Consequences of Customer Satisfaction: Do They Differ Across Online and Offline Purchases? J. Retail. 2019, 95, 10-23. [CrossRef]

59. Herhausen, D.; Miočević, D.; Morgan, R.E.; Kleijnen, M.H.P. The Digital Marketing Capabilities Gap. Ind. Mark. Manag. 2020, 90, 276-290. [CrossRef]

60. Zgolli, S.; Zaiem, I. Customer-to-customer Interaction in Tourism Experience: Moderating Role of Nationality. Arab Econ. Bus. J. 2017, 12, 44-56. [CrossRef]

61. Nathan, R.; Victor, V.; Gan, C.; Kot, S. Electronic Commerce for Home-based Businesses in Emerging and Developed Economy. Eurasian Bus. Rev. 2019, 9, 463-483. [CrossRef]

62. Kotler, P.; Armstrong, G.; Opresnik, M.O. Principles of Marketing, 11th ed.; Prentice Hall: Upper Saddle River, NJ, USA, 2006; pp. 90-179.

63. Guerin, C.; Jayatilaka, A.; Ranasinghe, D.; McCulloch, A.; Calder, P. Research Degrees in Information and Communication Technology (ICT): Why So Few Doctoral Students? J. Furth. High. Educ. 2017, 41, 625-641. [CrossRef]

64. Market, Market Halls. 2021. Available online: https:/ / piaconline.hu/ (accessed on 28 February 2021).

65. Hair, J.R., Jr.; Black, W.C.; Babin, B.J.; Anderson, R.E. Multivariate Data Analysis; Pearson Education Limited: Harlow, UK, 2014; pp. 313-340.

66. Marczyk, G.; DeMatteo, D.; Festinger, D. Essentials of Research Design and Methodology; John Wiley \& Sons Inc.: Hoboken, NJ, USA, 2005; pp. 83-89.

67. Wooldridge, J.M. Introductory Econometrics; South Western: Mason, OH, USA, 2013; pp. 584-589.

68. Park, K.H.; Kerr, P.M. Determinants of Academic Performance: A Multinomial Logit Approach. J. Econ. Educ. 1990, $21,101-111$. [CrossRef]

69. Sirin, Y.E.; Sahin, M. Investigation of Factors Affecting the Achievement of University Students with Logistic Regression Analysis: School of Physical Education and Sport Example. Sage Open 2020, 10, 1-9. [CrossRef]

70. Pyke, S.W.; Sheridan, P.M. Logistic Regression Analysis of Graduate Student Retention. Can. J. High. Educ. 1993, 23, 44-64. [CrossRef]

71. Hill, R.C.; Griffiths, W.E.; Lim, G.C. Principles of Econometrics, 4th ed.; John Wiley \& Sons Inc.: Hoboken, NJ, USA, 2011; pp. 595-598.

72. Gujarati, D.N. Basic Econometrics, 4th ed.; McGraw-Hill Companies: New York, NY, USA, 2004; pp. $593-615$.

73. Abebe, A.; Cherinet, Y.M. Factors Affecting the Use of Information and Communication Technologies for Cereal Marketing in Ethiopia. J. Agric. Food Inf. 2019, 20, 59-70. [CrossRef]

74. Haghzare, S.; Campos, J.L.; Bak, K.; Mihailidis, A. Older Adults' Acceptance of Fully Automated Vehicles: Effects of Exposure, Driving Style, Age, and Driving Conditions. Accid. Anal. Prev. 2021, 150, 105919. [CrossRef] [PubMed] 
75. Becic, E.; Edwards, C.J.; Manser, M.P.; Donath, M. Aging and the Use of an In-vehicle Intersection Crossing Assist System: An On-road Study. Transp. Res. Part F Traffic Psychol. Behav. 2018, 56, 113-122. [CrossRef]

76. Nekic, M.; Junakovic, I.T.; Ambrosi-Randic, N. Using the Internet in Older Age: Is it Important for Successful Aging? Suvrem. Psihol. 2016, 19, 179-193. [CrossRef]

77. Garcia-Villegas, J.D.; Garcia-Martinez, A.; Arriaga-Jordan, C.M.; Ruiz-Torres, M.E.; Rayas-Amor, A.A.; Dorward, P.; MartinezGarcia, C.G. Use of Information and Communication Technologies in Small-scale Dairy Production Systems in Central Mexico. Exp. Agric. 2020, 56, 767-779. [CrossRef]

78. Kawakami, T.; Parry, M.E. The Impact of Word-of-Mouth Sources on the Perceived Usefulness of an Innovation. J. Prod. Innov. Manag. 2013, 30, 1112-1127. [CrossRef]

79. Subejo, S.; Untari, D.W.; Wati, R.I.; Mewasdinata, G. Modernization of Agriculture and Use of Information and Communication Technologies by Farmers in Coastal Yogyakarta. Indones. J. Geogr. 2019, 31, 332-345. [CrossRef]

80. Vasquez, J.J.; Panadero, S.; Martin, R.; Diaz-Pescador, M.V. Access to New Information and Communication Technologies among Homeless People in Madrid (Spain). J. Community Psychol. 2015, 43, 338-347. [CrossRef]

81. Zhu, Q.; Lyu, Z.; Long, Y.; Wachenheim, C.J. Adoption of Mobile Banking in Rural China: Impact of Information Dissemination Channel. Socio Econ. Plan. Sci. 2021. [CrossRef]

82. Mumporeze, N.; Prieler, M. Gender Digital Divide in Rwanda: A Qualitative Analysis of Socioeconomic Factors. Telemat. Inform. 2017, 34, 1285-1293. [CrossRef]

83. Park, D.; Lee, J.; Han, I. The Effect of On-line Consumer Reviews on Consumer Purchasing Intention: The Moderating Role of Involvement. Int. J. Electron. Commer. 2007, 11, 125-148. [CrossRef]

84. Trusov, M.; Bucklin, R.E.; Pauwels, K. Effects of Word-of-Mouth Versus Traditional Marketing: Findings from an Internet Social Networking Site. J. Mark. 2009, 73, 90-102. [CrossRef]

85. Jing, X.; Xie, J. Group Buying: A New Mechanism for Selling Through Social Interactions. Manag. Sci. 2011, 57, 1354-1372. [CrossRef]

86. Zamarreño-Aramendia, G.; Cristòfol, F.J.; de-San-Eugenio-Vela, J.; Ginesta, X. Social-Media Analysis for Disaster Prevention: Forest Fire in Artenara and Valleseco, Canary Islands. J. Open Innov. Technol. Mark. Complex. 2020, 6, 169. [CrossRef]

87. Lazaro-Mojica, J.; Fernandez, R. Review Paper on the Future of the Food Sector through Education, Capacity Building, Knowledge Translation and Open Innovation. Curr. Opin. Food Sci. 2021, 38, 162-167. [CrossRef]

88. Jack, C.; Anderson, D.; Conolly, N. Innovation and Skills: Implications for the Agri-food Sector. Educ. Train. 2014, 56, 271-286. [CrossRef]

89. Grimsdottir, E.; Edvardsson, I.R. Knowledge Management, Knowledge Creation, and Open Innovation in Icelandic SMEs. Sage Open 2018, 8, 1-13. [CrossRef]

90. Yun, J.J.; Park, Y.; Gaudio, G.D.; Corte, V.D. Open Innovation Ecosystems of Restaurants: Geographical Economics of Successful Restaurants from Three Cities. Eur. Plan. Stud. 2020, 28, 2348-2367. [CrossRef]

91. Yun, J.J.; Zhao, X.; Jung, K.; Yigitcanlar, T. The Culture for Open Innovation Dynamics. Sustainability 2020, 12, 5076. [CrossRef]

92. Traitler, H.; Watzke, H.J.; Saguy, I.S. Reinventing R\&D in an Open Innovation Ecosystem. J. Food Sci. 2011, 76, 62-68. [CrossRef]

93. Lazarsfeld, P.F.; Berelson, B.; Gaudet, H. The People's Choice: How the Voter Makes Up His Mind in a Presidential Campaign, 2nd ed.; Columbia University Press: New York, NY, USA, 1948; pp. 1-224.

94. Steffes, E.M.; Burgee, L.E. Social Ties and Online Word of Mouth. Internet Res. 2009, 19, 42-59. [CrossRef] 